\title{
Factor Analysis of Learning Difficulties in E- learning for Students of History and Sociology Education Study Program IKIP Budi Utomo Malang in the Covid 19 Pandemic Era
}

\author{
Amanah Agustin * \\ Yulita Pujiharti ** \\ Lecturer at IKIP Budi Utomo, e-mail: ladyaribet@gmail.com \\ Ali Badar ** \\ Lecturer at IKIP Budi Utomo, e-mail: ali66badar@gmail.com \\ Loesita Sari** \\ Lecturer at IKIP Budi Utomo \\ DOI: 10.29322/IJSRP.12.01.2022.p12154 \\ http://dx.doi.org/10.29322/IJSRP.12.01.2022.p12154
}

Lecturer at IKIP Budi Utomo Malang History Education Study Program, Faculty of Social Sciences, e-mail: liatina.agustina @gmail.com

\begin{abstract}
The Indonesian government has taken a policy of closing schools to reduce contact in order to save human life as a result of the presence of Covid 19 as a new virus. Thus, the learning process is carried out at home through online learning/e-learning. IKIP Budi Utomo Malang helped to make the government program a success by providing affordable and quality education. This study aims to determine the application of e-learning and learning difficulties from the implementation of e-learning. This research includes qualitative research with phenomenological methods. The research subjects were students of class 2017 and lecturers of the History and Sociology Education Study Program. The research location is at IKIP Budi Utomo. The research instrument was an open questionnaire and a structured interview. The data analysis technique used inductive qualitative Seiddel. The results showed that the implementation of elearning for the lecturers of the History and Sociology Education Study Program was carried out using digital technology learning management system devices such as zoom meetings, google classroom, Siakad IKIP Budi Utomo Malang, youtube, video conferencing, telephone or live chat, edmodo and WhatsApp. E-learning learning is carried out properly in accordance with learning standards. While the difficulty factor experienced by lecturers is seeing the effectiveness of the learning process, measuring the level of student understanding, and understanding online learning tools. While the difficulties for students are internet signals, understanding of information technology in online learning, the burden of using quotas and the difference in the online learning atmosphere with face-toface learning
\end{abstract}

Index Terms- The difficulty factor, e-learning, Covid 19 Pandemic Era

\section{INTRODUCTION}

Human life in the world in general and in Indonesia in particular has undergone drastic changes due to the new virus Covid 19. In the field of education, the impact of Covid 19 is the closure of schools to reduce contact massively in order to save human life (Syah, 2020). On March 24, 2020, the Minister of Education and Culture of the Republic of Indonesia issued Circular Letter Number 4 of 2020 concerning the Implementation of Education Policies in the Emergency Period for the Spread of COVID, in the Circular it was explained that the learning process was carried out through online/distance learning at home only. (Dewi, 2020). Online/distance learning or Elearning is an educational system or concept that utilizes information technology in the teaching and learning process. Learning uses electronic or computer systems (Muzid \& Munir, 2005). Online/distance learning or E-learning learning is also defined as a learning system in which teachers and students do not have to meet face-to-face in the teaching and learning process. (Kusuma, 2011) Changes from classical conventional learning methods to e-learning by utilizing technology information, of course, encounter various obstacles. How students or students have to change learning patterns from direct guidance by teachers to indirect learning patterns through the media is certainly not easy for both students and teachers.

As one of the private universities whose outputs are quality "teachers", IKIP Budi Utomo Malang helps to make the government program a success by providing affordable and quality education. The change from classical conventional learning methods to e-learning by utilizing information technology will of course also cause various difficulties for students. Moreover, most of the students studying 
at IKIP Budi Utomo are overseas students. The characteristics of students studying in private universities will certainly be very different from students studying in state universities. Therefore, on this occasion the researchers conducted a study to analyze the Learning Difficulties Factors from Conventional Learning to E-learning Learning for Students of the History Education Study Program at IKIP Budi Utomo Malang in the Covid 19 Pandemic Era. The objectives to be achieved in this study are to determine: The application of elearning -learning on and Learning Difficulties Factors from Conventional Learning to E-learning Learning for Students of History and Sociology Education Study Program IKIP Budi Utomo Malang.

\section{RESEARCH METHOD}

This research includes descriptive research that provides an overview of a concept or symptom, also answers questions on the subject of discussion (Sumanto, 1995). The description of an e-learning learning concept is based on the implementation that has been carried out during the e-learning implementation. The main data sources are words and actions, the rest are additional data such as documents (Moleong, 2015). The data sources in this study were data on the implementation of e-learning learning in the History and Sociology education study program in 2020 and data on perceptions of lecturers and students participating in e-learning. Data collection is done by giving questionnaires to respondents and also by doing a literature study, namely: searching, researching, studying, recording, and interpreting data (Sugiyono, 2005). The data collected was analyzed by a logico-inductive process, which is a thought process that uses logic to understand patterns and trends in the data. Creswell (2015) says that narrative research is an attempt to understand an individual's experience by exploring problems. In addition, the researcher writes into stories that are rearranged chronological events that describe individual experiences in the past, present and future in a certain realm and context. The narrative is structured to describe the experiences of researchers and respondents in the period before the use of e-learning and when the implementation of e-learning was completed. What challenges are encountered in the implementation of e-learning so that the idea of implementing the e-learning learning model in the future in achieving learning objectives can be achieved optimally.

\section{RESULTS AND DISCUSSION}

\section{The application of e-learning to students of the History and Sociology study program at IKIP Budi Utomo}

In the middle of the even semester of 2019, namely at the beginning of March 2020, teaching and learning activities that were originally carried out on campus with a predetermined schedule have now become learning at home through online/e-learning. online learning is implemented as a result of the emergence of the COVID-19 pandemic. Lecturers are given the freedom in determining the online learning/e-learning that will be used.

The implementation of e-learning is carried out using a platform that helps lecturers to organize their learning. Based on the results of questionnaires distributed to lecturers and students, lecturers carry out online learning (e-learning) with digital technology learning management system devices such as Siakad (Academic Information System) IKIP Budi Utomo Malang, google classroom, zoom meeting, youtube, video conference, telephone or live chat, edmodo and WhatsApp. With this learning management system, lecturers can create learning classes and carry out the learning process starting from recruiting students, providing learning materials, monitoring student learning progress, giving assignments and giving assessments, to communicating for discussions related to the substance of learning as well as to motivate students.

Based on the questionnaire distributed to lecturers and students, the steps of e-learning learning carried out by lecturers varied, depending on the courses taught and the e-learning methods used. However, broadly speaking, the steps taken by lecturers are (a) providing materials/presentations through the e-learning portal in Siakad, Whatsapp Groups, Google Classroom or Edmodo. In addition to material in the form of papers/modules, lecturers also make learning videos which are then shown on various media such as YouTube, Facebook, Instagram and others. Materials can also be given directly through a zoom meeting or Google meet. (b) Giving assignments by lecturers in the form of group assignments or individual assignments with a set time and done by students with material sources from lecturers and from other sources (c) Discussions through zoom meetings, Google Classroom or Edmodo (d) Lecturers monitor and accompany the course discussion and question and answer and straighten the material if there are deviations (e) Assessment of learning outcomes is obtained through the value of assignments both individually and in groups and the value of the mid-semester and endsemester exams conducted online.

Moore (2018) in Tian Belawati (2019) states that e-learning as well as face-to-face classical learning must be prepared properly to be effective. The steps for e-learning are:

First, identify prospective learners who will take part in e-learning lessons 
Second, determine the learning objectives that must be achieved by the learner, what are the expected outcomes, how to arrange and sequence the goals that must be achieved so that students can easily achieve them step by step.

Third, determine the pedagogy to be used.

Fourth, determine the learning activities that will be used

Fifth, after knowing the activities and pedagogy that will be used, determine the e-learning learning platform that will be used and other devices that will be used to support learning.

Sixth, determine the material to be used

Seventh, determine how the assessment of learning outcomes will be carried out, and whether students will be given some kind of certificate after graduation.

Eighth, determine where the e-learning courses will be placed (in the study program, in the faculty, etc.), who is responsible for the operational learning facilities, what resources are needed, etc.

Ninth, identification of learning services that will be provided to students during e-learning in addition to the main ones.

Tenth, build a data analytics system that can record learning activities and outcomes. (Belawati, 2019)

The ten practices are in line with the steps for preparing courses in face-to-face learning according to the principles of educational technology. Based on the basic development steps of online learning, it can be depicted in the following figure:

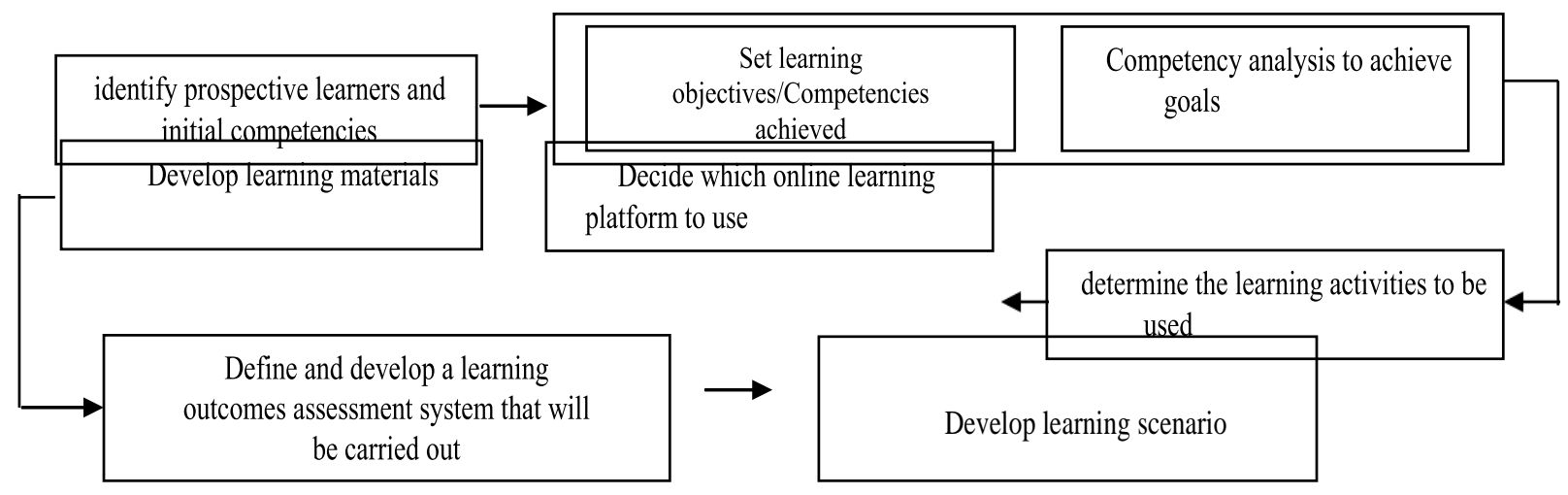

Figure 1. Flow of E-learning Learning Planning (Source: Belawati, 2019)

Based on input from the results of interviews and distributed questionnaires, the e-learning learning tools carried out by the History and Sociology Education Study Program lecturers went well. Because these learning tools provide features that simplify the learning process. Prasetyo (2018) states that LMS in general provides the following features. (a) Facility to upload and provide material in various formats. (b) Forum for asynchronous communication and Chat for synchronous communication and interaction. (c) Features to provide and check assignments, and (d) Data storage of learning process activities and grades. (Prasetyo, 2018)

Whatever the e-learning learning tools used by the History and Sociology education study program lecturers, they still prioritize quality. Due to the consideration of several general characteristics that support the quality standards of e-learning, such as (a) Multi-aspect comprehensive (multifaceted): the quality assurance system used covers various aspects of quality measurement, such as aspects of strategy, policy, infrastructure, process, output, and using a comprehensive and holistic approach, (b) Dynamic: the system is built to accommodate flexibility in dealing with changes in technology and even social norms (c) Becomes mainstream: the system is built to improve quality in all management lines, and is used as a reflection tool individually by lecturers and education personnel in carrying out their daily duties. (d) Representative: the system is designed to represent the perspectives and needs of various stakeholders, 
including the interests of learners, staff, institutions, government, and society in general and (e) Multi-functional: the system is created to perform other functions within the organization. (Tian Belawati, 2019)

\section{Learning Difficulty Factors from Conventional Learning to E-learning for Students of History Education Study Program IKIP Budi Utomo Malang}

Based on the results of the questionnaire distributed to lecturers and students the implementation of e-learning learning faced various kinds of obstacles. The obstacles experienced by lecturers are:

a. Lecturers find it difficult to measure the level of student understanding because they cannot meet face to face so that it is difficult to measure the effectiveness of the online learning process (e-learning). Lecturers do not know whether the material that has been given has been studied or not by students.

b. Lecturers find it difficult and do not understand various online learning tools, although they are always required to keep up with the times and technology. Lecturers sometimes feel lazy to learn more about technology and information.

While the difficulties experienced by students are:

a. About Internet signal, students find it difficult to get internet signal, especially for students who live outside Java. sometimes they have to leave their domicile area. According to one student, "The main difficulty is the 'signal'. Not all areas of our house have an adequate signal, so that sometimes it causes miscommunication with the lecturers.

b. Students also experience a lack of understanding of information technology. Students have difficulty downloading learning tools such as Google Classroom, Zoom Meeting or Edmundo, so that the learning process does not run between lecturers and students. Students cannot get the material and understand it because they cannot access the material given by the lecturer.

c. High fees for purchasing quotas. Many students are still in a poor economic condition so that the use of excessive quotas due to e-learning becomes a burden for them, especially at this time of difficult economic conditions due to the impact of the pandemic.

d. The difficulty experienced by other students is the difference in the online learning atmosphere with face-to-face. The student's expression "we often fail to understand the material explained by the lecturers because it feels different when learning in class (directly face to face) with e-learning time". In online learning the atmosphere is certainly different from when face to face, in a face-to-face atmosphere, students are required to be serious and serious in the learning process, of course different from online learning which does not feel supervised by the lecturer.

In line with the results of the questionnaire, according to Rizqon Halal Syah Aji (2020) who researched the Impact of Covid-19 on Education in Indonesia: Schools, Skills, and Learning Processes, the use of technology in online learning is certainly not without problems, there are many variances of problems that hinder its implementation. the effectiveness of learning with online methods include: (a) Limitations of Mastery of Information Technology both by teachers and by students. Constraints in understanding the use of information technology limit them in using online media. (b). Inadequate technology support facilities and infrastructure. The welfare of teachers and students limits them from enjoying information technology facilities and infrastructure which are very much needed by the Covid-19 disaster. (c). The internet network that is still not evenly distributed in remote parts of the country causes limited Internet access. (d) Lack of preparation of the Budget. There is a dilemma in the use of online media, when the Minister of Education encourages productivity to be accelerated, on the other hand, the skills and financial capabilities of teachers and students have not moved in the same direction. Even the state has not been fully present in facilitating the intended cost needs (Syah, 2020)

According to Grendi Hendrastomo, e-learning requires a system that is able to support the learning process. There are 4 components that support the success of the e-learning learning process, namely (a). Availability of internet access. E-learning learning, of course using and utilizing the internet network. The condition of the internet network in Indonesia in general is still relatively slow compared to developed countries. In addition, the availability of the internet network which is still not evenly distributed to remote villages is an obstacle for e-learning learning. (b). Computers (Hardware) as an intermediary between humans and the system are still very limited. The availability of computers with optimal internet speed is still constrained by the problem of price and the number of tools that are not proportional to the number of students who will access it, so that e-learning learning becomes constrained (c). System (Software) Learning e-learning or programs to facilitate the learning process (d). The cost of accessing the internet is still relatively expensive when compared to the speed of access obtained. When compared to conventional classes, the costs incurred to conduct e-learning are actually higher because the infrastructure required for the continuity of e-learning also requires a large investment. (Hendrastomo, 2008)

According to Tian Belawati (2019), the most important thing in the implementation of e-learning is the human resource aspect. In elearning, this schedule becomes "less" structured in terms of meetings and interactions. This is because the asynchronous communication feature in e-learning allows learners to "enter the classroom" anytime and from wherever they are. In the virtual world, learners' expectations are also very high that they will get a fast and even instant response. This can put pressure on the teacher as if he must "immediately" respond to all questions from students at any time. The opposite thing that deserves attention in e-learning learning is that often learners are less active, rarely "enter" their e-learning classes, rarely ask questions, rarely respond to posts by friends or teachers. Therefore, teachers must actively remind and trigger discussions in the "classroom" so that the learning process runs effectively. Teachers, in addition to providing teaching materials according to learning scenarios, also need to provide greetings that can motivate students to be disciplined, diligent, and remain committed to completing their learning to completion. 
Another thing that needs attention in the implementation of e-learning is conducting an assessment of learning outcomes. Based on the objectives, the assessment can be formative or summative. Formative assessments are usually carried out in the middle of the learning process with the aim of seeing student learning progress, so that their learning difficulties (if any) can be identified and given feedback so that the learning process becomes more effective. Formative assessment can also be done by providing questions to be answered by students. While the summative assessment is carried out at the end of the learning process with the aim of measuring whether the learning outcomes are in accordance with the learning objectives that must be achieved and can be used to determine graduation. (Belawati, 2019)

To get effective learning outcomes, the implementation of e-learning must be prepared properly according to the needs and situations. All aspects, both technical and non-technical aspects, really support the implementation of effective e-learning.

\section{CONCLUSION}

The teaching and learning process which was originally carried out on campus face to face with a predetermined schedule has changed to learning at home via online / e-learning due to the emergence of the COVID-19 pandemic. The implementation of e-learning for the lecturers of the History and Sociology Education Study Program is carried out using a learning management system. E-learning learning tools that are often used are Siakad (Academic Information System) IKIP Budi Utomo Malang, google classroom, zoom meeting, youtube, video conference, telephone or live chat, edmodo and WhatsApp. With this learning management system, lecturers can create learning classes and carry out the learning process.

The implementation of e-learning conducted by lecturers and students of the History and Sociology Education Study Program certainly faces various kinds of obstacles. Obstacles experienced by lecturers are difficulties in seeing the effectiveness of students in the online learning process (e-learning) and difficulties in measuring students' level of understanding. Besides, not all lecturers understand about various online learning tools, and difficulties in keeping up with technological and information developments. While the difficulties experienced by students are the absence or lack of internet signal, lack of understanding of information technology, and financing in the use of excessive quotas due to e-learning.

\section{REFERENCES}

[1] Azis, I. (2020). Mengenal Google Classroom: Fungsi dan Cara Menggunakannya. New Pedagogical Thought, Vol. 101, pp. 27-32. https://doi.org/10.37026/25206427-2020-101-1-27-32

[2] Belawati, T. (2019). Pembelajaran Online.

[3] Creswell, John W. 2015. Penelitian Kualitatif \& Desain Riset. Yogyakarta : Pustaka Pelajar.

[4] Dewi, W. A. F. (2020). Dampak COVID-19 terhadap Implementasi Pembelajaran Daring di Sekolah Dasar. Edukatif: Jurnal Ilmu Pendidikan, 2(1), 55-61. https://doi.org/10.31004/edukatif.v2i1.89.

[5] Gisny. (2015). Pengertian, Fungsi, Kegunaan, Kelebihan, dan Kekurangan Edmodo. Retrieved from https://aboutgirlsite.wordpress.com/2015/11/02/pengertianfungsi-kegunaan-kelebihan-dan- kekurangan-edmodo/

[6] Hendrastomo, G. (2008). Dilema dan Tantangan Pembelajaran E-learning 1 (The Dilemma and the Challenge of. Majalah Ilmiah Pembelajaran, 4, 1-13. Retrieved from http://staff.uny.ac.id/sites/default/files/132318574/Dilema dan Tantangan Pembelajaran Elearning ok.pdf

[7] Kusuma, A. (2011). E-LEARNING DALAM PEMBELAJARAN. Lentera Pendidikan, 14, 35-51

[8] Moleong, Lexy J.2015.Metode Penelitian Kualitatif.Bandung:Remaja Rosdakarya

[9] Muzid, S., \& Munir, M. (2005). Persepsi Mahasiswa Dalam Penerapan e-learning sebagai Aplikasi Peningkatan Kualitas Pendidikan (Studi Kasus Pada Universitas Islam Indonesia). Seminar Nasional Aplikasi Teknologi Informasi 2005 (SNATI 2005), 2005(Snati), 8

[10] Prasetyo, D.A. (2018). Perangkat lunak sistem pengelolaan pembelajaran daring. Makalah tidak dipublikasikan

[11] Schmidt, R., Schmidt, J., \& Kreienkamp, J. (2020). Zoom Meeting: Definisi hingga Cara Menggunakannya. Retrieved from https://zoom.us/s/97320123989

[12] Sugiyono, 2005. Memahami penelitian kualitatif. Bandung : Alfabeta

[13] Suhendar, A. (2019). Efektifitas E-learning dalam Sistem Pembelajaran Orang Dewasa (Studi Kasus pada Pelatihan Dasar Calon Pegawai Negeri Sipil Angkatan ke 1 sampai ke 5 di Pusat Pelatihan dan Pengembangan dan Pemetaan Kompetensi Aparatur Sipil Negara Lembaga Administrasi Neg. SEMINAR KEPENDUDUKAN, KELUARGA DAN SUMBER DAYA MANUSIA 2019, 8-18.

[14] Sumanto.M.A., 1995 , Metodologi Penelitian Sosial Dan Pendidikan, Yogyakarta : Andi Offset

[15] Syah, R. H. (2020). Dampak Covid-19 pada Pendidikan di Indonesia: Sekolah, Keterampilan, dan Proses Pembelajaran. SALAM: Jurnal Sosial Dan Budaya SyarI, 7(5). https://doi.org/10.15408/sjsbs.v7i5.15314

\section{AUTHORS}

First Author - Author name, qualifications, associated institute (if any) and email address.

Second Author - Author name, qualifications, associated institute (if any) and email address. 

ISSN 2250-3153

Third Author - Author name, qualifications, associated institute (if any) and email address.

Correspondence Author - Author name, email address, alternate email address (if any), contact number. 